\title{
PENGEMBANGAN MEDIA PEMBELAJARAN IPS DENGAN TEMA PEMANFAATAN DAN PELESTARIAN SUNGAI UNTUK SISWA KELAS VII SMP
}

\author{
Dendi Tri Suarno, Sukirno \\ Program Studi Ilmu Pengetahuan Sosial (IPS), Universitas Negeri Yogyakarta \\ denditrisuarno@gmail.com, soekirno_uny@yahoo.co.id
}

\begin{abstract}
Abstrak
Tujuan penelitian ini adalah menghasilkan media yang layak dan efektif digunakan dalam pembelajaran IPS dengan tema pemanfaatan dan pelestarian sungai untuk siswa kelas VII SMP. Penelitian ini termasuk jenis penelitian dan pengembangan. Hasil penelitian ini adalah berupa multimedia pembelajaran dalam bentuk CD program, yang telah dinilai dengan skala lima menunjukkan bahwa:(1) aspek pembelajaran dengan skor 4,64 "sangat layak"; (2) aspek materi dengan skor 4,83 "sangat layak" (3) penilaian ahli media pada aspek media dengan skor 3,92 "layak". Hasil uji coba lapangan menunjukkan bahwa: (1) uji coba lapangan awal dengan skor 4,04 "layak"; (2) uji coba lapangan utama dengan skor 4,14 "sangat layak"; (3) uji coba lapangan operasional dengan skor 4,19 "sangat layak". Hasil tes uji coba efektivitas lapangan menunjukkan skor ketuntasan belajar siswa sebesar 76,4 (melampaui KKM yaitu 75,0), aspek sikap sebesar 84,36 "sangat baik" dan skor aspek keterampilan sebesar 71,88 "baik".
\end{abstract}

Kata kunci: pengembangan media pembelajaran IPS

\author{
DEVELOPING OF SOCIAL STUDIES LEARNING MEDIA FOR \\ SEVENTH GRADE STUDENTS OF JUNIOR HIGH SCHOOL WITH \\ THE THEME 'THE UTILIZATION AND PRESERVATION OF RIVERS \\ Dendi Tri Suarno, Sukirno \\ Program Studi Ilmu Pengetahuan Sosial (IPS), Universitas Negeri Yogyakarta \\ denditrisuarno@gmail.com, soekirno_uny@yahoo.co.id
}

\begin{abstract}
This research aims to produce appropriate and efective media in social studies learning for seventh grade students of junior high school with the theme 'the utilization and preservation of rivers'. This was Research and Development $(R \& D)$. The result of this research is an multimedia in the form of $C D$ program based on the evaluation of content expert with scale five shows that:(1) the learning aspect "very appropriate" It was known that the score was 4.64; (2) the content aspect "very appropriate" It was known that the score was 4.83; (3) the evaluation of media expert in media aspect "appropriate" It was known that the score was 3.92. The result of field testing shows that: (1) on the preliminary field testing, the score is 4.04 "appropriate"; (2) On the main field testing, the score was 4.14 "very appropriate"; 3 ) on the the operational field testing, the score is 4.19 "very appropriate". The result of the effectiveness field testing shows that average score 76.4, (passing grade with average score 75.0), on the attitudes aspects score is 84.36 "very good" and on the skills aspects score is 71.88 "good".
\end{abstract}

Keywords: developing of social studies learning media 


\section{Pendahuluan}

Keberadaan teknologi yang semakin canggih dan percepatan aliran informasi menjadi dasar dari pergeseran paradigma, khususnya dalam era informasi. Salah satu bidang yang mendapatkan dampak yang positif cukup berarti dalam perkembangan IPTEK di era globalisasi adalah bidang pendidikan berupa penggunaan teknologi informasi yang diterapkan dalam pembelajaran memudahkan proses penyampaian informasi dari guru ke siswa. Pendidikan merupakan suatu proses komunikasi dan informasi antara guru kepada siswa yang berisi informasi-informasi pendidikan, yang memiliki unsur-unsur guru sebagai sumber informasi, media sebagai sarana penyajian ide, gagasan dan materi pendidikan siswa itu sendiri. Oleh karena itu, pendidikan harus mendapat perhatian yang lebih dari penentu kebijakan pengeloa pendidikan agar peningkatan mutu pendidikan menuju ke arah yang lebih baik.

Dalam meningkatkan kualitas pendidikan nasional, pemerintah telah melakukan berbagai upaya diantaranya pengembangan dan perbaikan standar kelulusan, pengembangan standar isi, perbaikan standar proses pendidikan, pengembangan sarana dan prasarana, perbaikan standar pengelolahan, standar pembiayaan, standar penilaian peningkatan standar pendidik dan tenaga kependidikan. Pada standar proses pendidikan kegiatan belajar mengajar guru memiliki berbagai peran dan fungsi yang sangat penting. Sebagai perencana pengajaran, seorang guru diharapkan mampu untuk merencanakan kegiatan belajar mengajar secara efektif. Untuk itu guru harus memiliki pengetahuan yang cukup tentang prinsip-prinsip belajar sebagai dasar dalam merancang kegiatan belajar mengajar, seperti merumuskan tujuan pembelajaran, memilih model pembelajaran, memilih media, menetapkan evaluasi dan sebagainya. Sebagai pengelola pengajaran, seorang guru harus mampu mengelolah seluruh proses kegiatan pembelajaran dengan menciptakan kondisi belajar sedemikian rupa sehingga siswa dapat belajar secara efektif dan efisien.

Demi terciptanya situasi belajar yang menyenangkan dan menarik minat siswa, guru dituntut kreatif dalam mengelola pembelajaran di kelas. Untuk meningkatkan minat siswa, guru dituntut untuk menjadikan pelajaran lebih inovatif yang dapat mendorong siswa untuk belajar secara optimal, baik belajar mandiri maupun dalam pembelajaran di kelas dengan metode yang inovatif, alat peraga atau media lainnya.

Komunikasi memegang peranan penting dalam pembelajaran. Agar komunikasi antara guru dan siswa berlangsung baik dan informasi yang disampaikan guru dapat diterima siswa, guru perlu menggunakan media pembelajaran. Pembelajaran secara lisan membuat siswa kesulitan memahami materi secara mendalam sehingga guru harus kreatif dalam menggunakan media sebagai perantara penyampaian materi yang diajarkan. Kegiatan belajar mengajar melalui media terjadi bila adanya perantara komunikasi antara guru (sumber) dan siswa (penerima). Fungsi media pembelajaran adalah sebagai alat bantu mengajar, yakni menunjang penggunaan metode mengajar yang digunakan guru. Oleh karena itu, media pembelajaran yang digunakan harus efektif dan selektif sesuai dengan pokok bahasan yang diajarkan.

Pada saat ini telah banyak ditemukan berbagai media pembelajaran dipasaran yang disediakan dalam bentuk CD atau DVD. Contoh-contoh yang dapat kita temukan seperti ensiklopedia, kamus elektronik, buku cerita elektronik, dan materi pembelajaran dalam bentuk flash, lectora, serta PowerPoint. Di dalam media tersebut konsep permainan dalam pembelajaran digabung untuk menghasilkan pengalaman pembelajaran yang menyenangkan. Siswa lebih senang pembelajaran menggunakan media karena dapat menjelaskan secara visual dan konkret mengenai materi yang disampaikan guru. Penggunaan media juga dapat mengaktifkan berbagai indera siswa dalam merespon pembelajaran sehingga pemahaman terhadap materi dapat tercapai. Akan tetapi, dalam penerapannya di sekolah media pembelajaran masih belum optimal dan merata digunakan sebagai sarana belajar.

Berdasarkan berita hariann Kompas pada tanggal 15 Februari 2013 bahwa sekolah yang menerapkan teknologi informasi dan komunikasi dalam pembelajaran masih minim. Padahal, pemanfaatan teknologi informasi dan komunikasi dalam pembelajaran menjadi kebutuhan yang penting, dalam menyelenggarakan pendidikan abad 21. Apalagi, Kurikulum 2013 menuntut agar perubahan pembelajaran 
dengan memanfaatkan teknologi informasi dan komunikasi (TIK) sudah keharusan.

Akan tetapi, sampai saat ini pemerataan pemanfaatan TIK dalam pembelajaran di semua jenjang sekolah dari SD, SMP, hingga SMA/SMK yang sederajat belum tercapai. Dalam berita tersebut juga, Kementerian Pendidikan dan Kebudayaan pada tahun 2013, mencatat 24 persen jenjang SD sederajat yang menerapkan TIK dalam pembelajaran, sedangkan di jenjang SMP sebanyak 40 persen di terapkan dalam pembelajaran. (http://edukasi. kompas.com/read/2013/02/15/20402882/Pem anfaatan.TIK.di.Sekolah.Minim.)

Berdasarkan observasi kegiatan pembelajaran IPS di kelas VII dan wawancara terhadap guru IPS di Kabupaten Sleman yaitu SMP Negeri 3 Ngaglik dan SMP Negeri 3 Pakem tanggal 9 Agustus 2014, serta dilanjutkan pada tanggal 25 Agustus 2014 di SMP Muhammadiyah 3 Mlati diperoleh beberapa informasi mengenai permasalahan dalam pembelajaran IPS, diantaranya latar belakang guru IPS yang mengajar bukan dari IPS terpadu, sehingga pemahaman terhadap pembelajaran terpadu masih mengalami kesulitan.

Mayoritas guru yang mengajar pembelajaran IPS di tiga sekolah tersebut memiliki latar belakang keilmuan seperti akuntansi murni, geografi, dan ekonomi. Pada prinsipnya di tingkat sekolah menengah pertama, mata pelajaran IPS masih bersifat monodisipliner, yakni terdapat mata pelajaran sejarah, geografi, sosiologi dan ekonomi (Supardi, 2011, p.216). Sehingga penerapan pembelajaran IPS terpadu maka proses pengajaran mengarah pada tematik agar pembelajaran lebih bermakna dan holistik.

Akan tetapi kenyaataan di lapangan IPS masih di ajarkan secara parsial atau terpisah seperti sejarah, ekonomi, sosiologi dan geografi. Dalam proses pembelajaran IPS guru juga kurang dalam mengembangkan kegiatan pembelajaran yang inovatif dan menarik. Guru masih menggunakan model konvensional dan tidak bervariasi yang membuat siswa bosan dan jenuh terhadap mata pelajaran IPS. Hal itu terlihat ketika siswa mengikuti pelajaran kurang serius, tidak memperhatikan saat guru menjelaskan, ribut sendiri, cenderung main-main di kelas, dan tidak ingin bertanya mengenai materi yang belum dipahami. Indikasi tersebut menunjukkan kurangnya motivasi belajar siswa dalam mengikuti pelajaran di kelas. Guru sering menggunakan media yang telah tersedia yaitu textbook, selain itu metode ceramah masih mendominasi dalam proses pembelajaran sehingga model pembelajaran cenderung berpusat pada guru.

Permasalahan lain yang ditemukan dalam hasil observasi menyoroti perubahan kurikulum yang baru (Kurikulum 2013) masih membingungkan guru IPS. Kebijakan sekolah yang menerapkan kurikulum 2013 membuat sekolah perlu memahami pelaksanaan hal itu, dikarenakan tahun sebelumnya ketiga sekolah yang telah diobservasi masih menggunakan kurikulum KTSP. Oleh karena itu, guru IPS masih binggung dalam mengajarkan materi IPS. Materi IPS yang di ajarkan dalam kurikulum 2013 belum terpadu pembahasannya.

Ketersedian bahan ajar kurikulum 2013 berupa buku paket masih kurang dan setiap tema-tema yang diajarkan belum di buat dalam bentuk media pembelajaran karena pembelajaran masih berpedoman pada buku paket yang diberikan dari pemerintah pusat. Materi yang bersifat proses seperti siklus hidologi dan sungai sangat cocok jika kembangkan menggunakan media seperti animasi proses siklus hidrologi yang menghasilkan air di sungai dan di laut. Akan tetapi, di ketiga sekolah yang telah di observasi materi hidrologi dan sungai belum di kembangkan dalam bentuk media baik berupa animasi, maupun media visual lainnya. Pembelajaran IPS yang dirancang secara baik dan kreatif dengan memanfaatkan teknologi multimedia, dalam batas-batas tertentu akan akan dapat memperbesar pemahaman peserta didik dalam mencapai kompetensi.

Perubahan kurikulum 2013 yang baru membuat cara mengajar dari KTSP menjadi terpadu dengan tema-tema, akan tetapi karena masih bersifat baru tema-tema tersebut belum dikembangkan atau tersedia dalam bentuk media. Penggunaan media pembelejaran IPS masih kurang, karena hanya media buku paket yang sering digunakan dalam pembelajaran. Media-media seperti flash, lectora, video, multimedia, atau pun slide powerpoint jarang digunakan dalam proses pembelajaran. Padahal, materi yang bersifat abstrak, proses, maupun konkret harus diajarkan melalui media agar dapat meningkatkan pemahaman siswa. Hal itu menjadi kendala dalam penyampaian materi yang menyajikan tema-tema dalam pembelajaran IPS. 
Dalam pembelajaran IPS, tema-tema yang diajarkan kebanyakan bersifat teoritis, sehingga siswa memerlukan waktu yang lama untuk memahami materi-materi tersebut. Kesulitan siswa dalam memahami materi dapat dibantu dengan visualisasi media. Materi disusun dari tema-tema yang dikembangkan dalam berbagai aspek baik geografi, sejarah, ekonomi, dan sosiologi. Akan tetapi pembelajaran tematik dalam penjelasannya tidak cukup hanya dengan lisan.

Oleh sebab itu, untuk mempelajari dan memahami proses tersebut bisa dilakukan dengan mengkaji teori-teori yang sudah ada dan dipadukan dengan penggunaan media yang bisa menganimasikan dan memvisualisasikan bagaimana proses-proses tersebut terjadi. Media merujuk pada apa saja yang membawa informasi antara sebuah sumber dan penerima, dalam konteks pendidikan tentunya media mempunyai peran dalam penyampaian materi kepada siswa (Sharon, 2011, p.7)

Kata "media" berasal dari bahasa Latin dan merupakan bentuk jamak dari kata "medium", yang secara harfiah berarti "perantara atau pengantar". Dengan demikian, media merupakan wahana penyalur informasi belajar atau penyalur pesan (Djamarah \& Zain, 2006, p.120). Media adalah perantara atau pengantar pesan dari pengirim ke penerima pesan (Sadiman, 2005, p.6). Media adalah suatu perangkat yang dapat menyalurkan informasi dari sumber ke penerima informasi (Yamin, 2007, p.197). Berdasarkan beberapa definisi di atas dapat di simpulkan media adalah suatu perangkat perantara yang digunakan untuk menyampaikan informasi dari pengirim ke penerima pesan agar terjadinya timbalbalik dalam sebuah komunikasi.

Dale seperti dikutip oleh Arsyad (2011, p.10) menyatakan "kurang lebih 75\% hasil belajar seseorang diperoleh melalui indera pandang, melalui indera dengar sekitar $13 \%$ dan melalui indera lainnya sekitar 12\%". Membaca hasil tersebut dapat disimpulkan bahwa media pembelajaran sangat berperan dalam proses belajar siswa. Hal ini dikarenakan media mampu memvisualisasikan konsep yang abstrak ke dalam bentuk visual yang dapat diamati oleh indera pandang.

Berdasarkan analisis tersebut diketahui bahwa dalam pembelajaran IPS dengan tema-tema yang bersifat konstekstual berupa kejadian atau fenomena sosial di kehidupan nyata dapat dihadirkan dalam sebuah media pembelajaran yang menarik dalam bentuk multimedia, sehingga dapat membantu siswa dalam memahami materi secara mendalam. Multimedia dapat menggantikan fungsi utama guru sebagai pengajar utama sumber belajar (Yudhi, 2013, p.152). Hal itu dikarenakan dengan pembelajaran dengan multimedia siswa dapat belajar secara mandiri. Multimedia sebagai kata benda yang merujuk pada teknologi untuk menyajikan materi dalam bentuk verbal dan visual (Mayer, 2009, p. 4). Multimedia merupakan suatu sistem penyampaian dengan menggunakan berbagai jenis bahan belajar yang membentuk suatu unit atau paket (Susilana \& Ryana, 2008, p.21). Multimedia berhubungan dengan penggunaan lebih dari satu macam media untuk menyajikan informasi (Munir,2012, p.2). Dari beberapa pendapat di atas dapat di simpulkan bahwa multimedia merupakan seperangkat bahan ajar yang merupakan satu kesatuan dari mediamedia yang ada untuk menyampaikan materi pelajaran.

Melihat permasalahan tersebut peneliti berupaya untuk menyelesaikan permasalahan tersebut, dengan melakukan penelitian pengembangan multimedia sebagai media pembelajaran IPS. Berawal dari berbagai hal yang telah dipaparkan dan dikaji dengan teori pembelajaran media, maka peneliti mengadakan penelitian tentang "pengembangan multimedia pembelajaran IPS dengan tema pemanfaatan dan pelestarian sungai untuk siswa kelas VII SMP”

\section{Metode Penelitian}

\section{Jenis Penelitian}

Penelitian ini menggunakan model penelitian dan pengembangan (research and development) yang berorientasi pada produk. Borg \& Gall mendefinisikan penelitian pengembangan sebagai berikut (Borg \& Gall, 2003, p.775):

Research and development $(R \& D)$ is the use of research findings to design new products and procedures, followed by the application of research methods to field-test, evaluate, and refine the products and procedures until they meet specified criteria of effectiveness, quality, or similar standars. 
Penelitian dan pengembangan (R \& D) adalah penelitian yang digunakan untuk menemukan desain produk yang baru dan prosedur mengikuti aplikasi metode penelitian menggunakan uji coba lapangan, evaluasi, dan merevisi produk serta prosedur sampai memenuhi kriteria keefektivan, kualitas atau sesuai standar yang ada.

\section{Waktu,Tempat, dan Subjek Penelitian}

Penelitian ini dilakukan pada Bulan tanggal 5 Januari - tanggal 29 Januari 2015 di sekolah SMP Negeri 3 Ngaglik, SMP Negeri 3 Pakem dan SMP Muhammadiyah 3 Mlati. Dengan pemilihan berdasarkan perwakilan dari sekolah dengan akreditasi A, B dan C.

Subjek penelitian dalam pengembangan multimedia adalah siswa kelas VII
SMP Negeri 3 Ngaglik, SMP Negeri 3 Pakem dan SMP Muhammadiyah 3 Mlati yang berjumlah 132 orang siswa tahun ajaran 2014/ 2015 dan 3 guru IPS.

Prosedur Penelitian

Berdasarkan model penelitian dan pengembangan Borg \& Gall dan desain pembelajaran (Dick \& Carey,2009, p.6), peneliti melakukan adaptasi/modifikasi untuk melakukan sebuah model pengembangan yang cocok dan sesuai. Sesuai dengan model pengembangan prosedur pengembangan media pembelajaran IPS dengan tema pemanfaatan dan pelestarian sungai untuk siswa kelas VII SMP dalam penelitian ini yakni sebagai berikut:

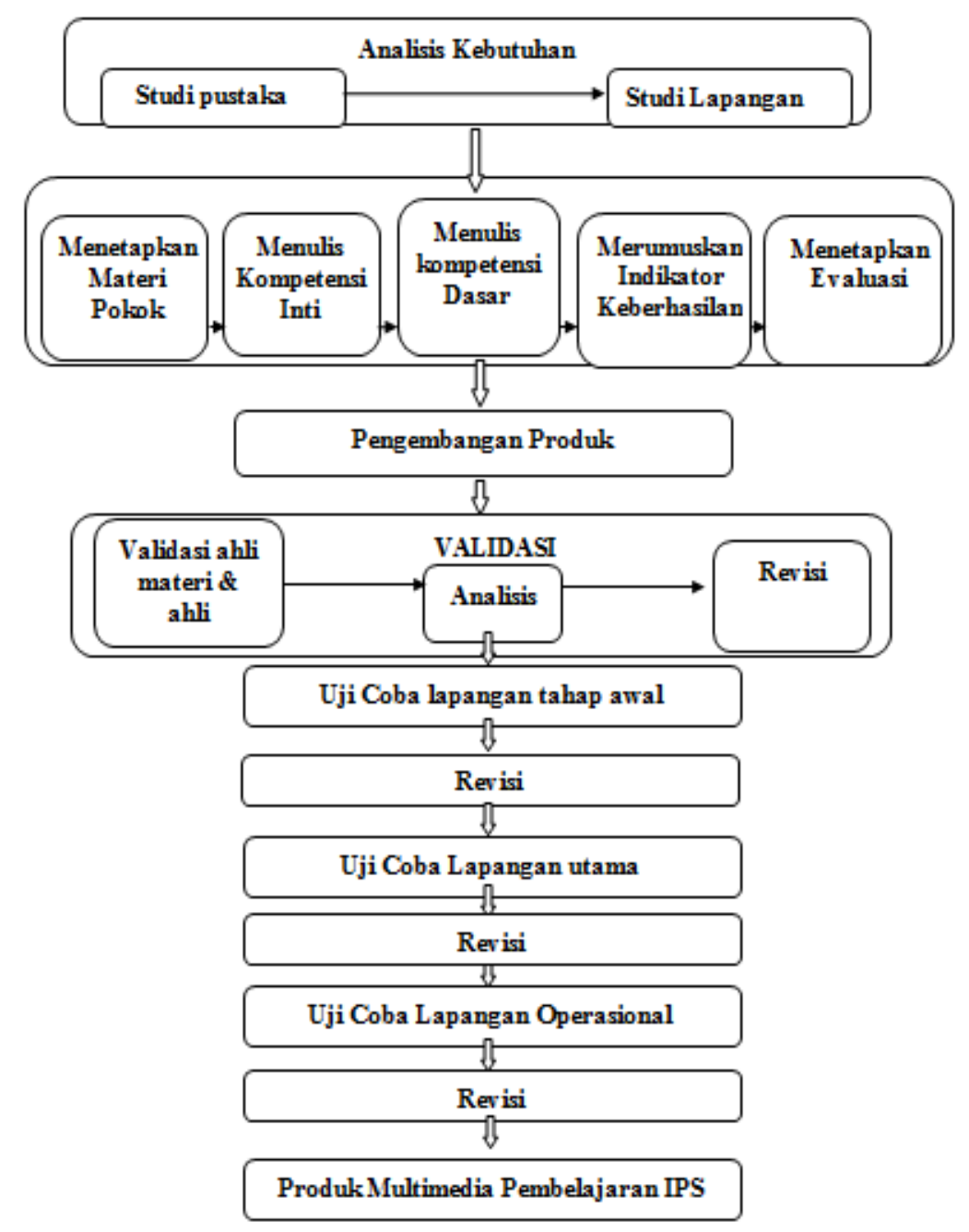

Gambar 1. Prosedur Pengembangan Media Lectora Inspire untuk Pembelajaran (Diadaptasi dari Borg \& Gall dan Dick \& Carey) 
Teknik dan Instrumen Pengumpulan Data

\section{Teknik Pengumpulan Data}

Dalam penelitian ini menggunakan data kualitatif berupa tanggapan tentang kelayakan produk dari ahli media dan ahli materi, serta guru dan siswa. Skor penilaian tentang kelayakan produk dari ahli media meliputi tentang aspek tampilan dan aspek pemrograman. Skor penilaian dari ahli materi meliputi aspek pembelajaran dan aspek materi. Skor penilaian dari guru dan siswa meliputi aspek pembelajaran, materi, tampilan dan pemrograman.

Salah satu prosedur yang harus diperhatikan dalam pengembangan media adalah kelayakan. Kelayakan media adalah penelitian dan penilaian tentang dapat tidaknya sebuah media berhasil di masyarakat. Kelayakan dilakukan untuk mengetahui pantas tidaknya produk itu dibuat.

Tujuan dari evaluasi program media itu diantaranya (Arsyad, 2011, p.174) adalah: (1) menentukan apakah media itu efektif, (2) memilih media yang sesuai untuk pembelajaran, (4) menentukan apakah isi pelajaran sudah tepat disajikan dengan yang dimaksud, (5) mengetahui apakah media itu benar-benar memberikan sumbangan hasil belajar seperti yang dinyatakan, serta (6) mengetahui sikap siswa terhadap media pembelajaran.

Untuk mendapatkan data tentang keefektifan produk multimedia yang diujicobakan, digunakan prosedur sebagai berikut (1) Mengadakan pre-test, untuk mengetahui pengetahuan awal yang telah dimiliki oleh siswa. (2) menguji coba produk multimedia melalui pembelajaran dan (3) mengadakan post-test untuk mengetahui sejauh mana pengetahuan yang diperoleh siswa setelah dilakukan kegiatan pembelajaran dengan menggunakan mulitimedia.

Efektifitas mengacu pada indikator belajar yang tepat (seperti tingkat prestasi dan kefasihan tertentu) untuk mengukur hasil pembelajaran (Reigeluth, 2009, p.77) Efektivitas berkaitan dengan sejauh mana siswa mencapai tujuan pembelajaran yang ditetapkan, yaitu, sekolah, perguruan tinggi, atau pusat pelatihan mempersiapkan siswa dengan pengetahuan, keterampilan, dan sikap yang diinginkan oleh para stakeholder (Januszewski \& Molenda, 2008, p.57).
Pengukuran keefektivitasan hasil belajar tentu berbeda-beda. Hal ini sendiri ditentukan oleh jenis mata pelajaran serta janjang sekolah yang menerapkannya. Misalnya untuk mengetahui efektivitas pelajaran IPS di SMP hasil belajar siswa maka guru perlu melihat ketuntasan kriteria minimum (KKM). Pada penelitian ini dilakukan di SMPN 3 Ngaglik, SMPN 3 Pakem, dan SMP Muhammadiyah 3 Mlati di Kabupaten Sleman yang diketahui bahwa KKM ketiga sekolah tersebut untuk mata pelajaran IPS adalah 75. Oleh sebab itu, maka pelajaran IPS dikatakan efektif jika hasilnya lebih dari KKM yang ditentukan atau nilainya melebihi hasil belajar sebelumnya.

\section{Instrumen Pengumpulan Data}

Instrumen yang digunakan untuk mengumpulkan data pada penelitian ini berupa angket. Angket digunakan untuk mengumpulkan data-data kuantitatif. Data-data ini digunakan untuk mengetahui kelayakan produk yang dikembangkan. Instrumen penelitian berupa angket berdasarkan kisi-kisi yang telah dikembangkan instrumen dikutip dari Kustandi \& Sutjipto (2013, pp.144-151).

Teknik analisis data

Teknik analisis dalam penelitian ini menggunakan teknik deskriptif kuantitatif. Data yang diperoleh melalui angket dari ahli materi dan ahli media, guru dan siswa terhadap produk yang dikembangkan kemudian dianalisis. Dalam angket disediakan lima pilihan untuk memberikan tanggapan tentang kelayakan produk yang dikembangkan, yaitu: : sangat layak (5), layak (4), cukup layak (3), kurang layak (2), sangat kurang layak (1). Skor acuan tabel yang dikutif dari Sukarjo (2005, p.55). Pedoman mengubah kuantitaif menjadi kualitatif disajikan pada Tabel 1 .

Tabel 1. Pedoman Pengubahan Data Kuantitatif Menjadi Data Kualitatif

\begin{tabular}{ccc}
\hline Interval & Nilai & Kategori \\
\hline $\mathrm{X}>4,08$ & A & Sangat Layak \\
\hline $3,36<\mathrm{X} \leq 4,08$ & $\mathrm{~B}$ & Layak \\
\hline $2,64<\mathrm{X} \leq 3,36$ & $\mathrm{C}$ & Cukup Layak \\
\hline $1,92<\mathrm{X} \leq 2,64$ & $\mathrm{D}$ & Kurang Layak \\
\hline $\mathrm{X} \leq 1,92$ & E & Sangat Tidak Layak \\
\hline
\end{tabular}


Dalam pengujian efektivitas peneliti dapat memberikan suatu kriteria penilaian nilai persentase siswa yang mencapai ketuntasan belajar, serta penentuan dalam kategori nilai kualitatif. SMP di Kabupaten Sleman menentukan KKM minimal "75" ( nilai ratarata yang digunakan ketuntasan belajar). Demikian jika siswa mnedapat nilai 75 dalam post tes, maka siswa tersebut dinyatakan "tuntas." Kemudian membandingkan skor rata-rata dengan skor media. Apabila skor yang diperoleh lebih besar atau sama dengan skor media maka produk dikategorikan efektif. Sebaliknya jika skor yang diperoleh kurang dari media maka produk dikategorikan tidak efektif.

\section{Hasil Penelitian dan Pembahasan}

Produk ini berupa compact disk (CD) multimedia pembelajaran untuk siswa kelas VII. Program ini dikembangkan dengan menggunakan software dari Lectora Inspire. Tahap persiapan produksi dilakukan dengan pengembangan desain pembelajaran yang meliputi analisis pembelajaran, mengindentifikasi kompetensi inti, karakteristik siswa, merumuskan kompetensi dasar dan indikator, mengembangkan butir tes, menyusun strategi pembelajaran, mengembangkan materi, merancang sistem penilaian dan merancang desain evaluasi.

Pada pengembangan materi dikumpulkan gambar-gambar dan musik pendukung serta video dan membuat animasi. Teks pendukung juga disiapkan. setelah itu, dilakukan pengembangan desain pada media. Sebelum produk ini diuji kelayakannya oleh ahli materi dan ahli media, produk tersebut sudah dilakukan ujicoba secara internal yaitu ujicoba jalannya program secara keseluruhan, dan secara eksternal yaitu ujicoba ke beberapa komputer dan laptop yang setara dengan pentium IV maupun ke spesifikasi di atasnya. Produk multimedia hasil pengembangan tahap awal dapat dideskripsikan sebagai berikut: Produk multimedia pada pembelajaran IPS kelas VII berbentuk kepingan $\mathrm{CD}$ yang berisi paket pembelajaran IPS dengan materi siklus hidrologi, pengertian sungai, jenis-jenis sungai, pola aliran sungai, karakteristik sungai, manfaat sungai, pencemaran sungai dan pelestarian sungai.
Hasil penilaian media validasi oleh ahli materi dan dan media serta uji coba yang dilakukan pada guru dan siswa multimedia yang dikembangkan sangat layak digunakan sebagai media pembelajaran yang ditinjau dari aspek pembelajaran, materi dan media.

Berdasarkan penilaian ahli materi terhadap kelayakan produk ditinjau dari aspek pembelajaran diketahui bahwa rerata skor sebesar 4,64 dengan kategori "sangat layak" dan aspek materi sebesar 4,83 dengan kategori "sangat layak". Penilaian ahli materi pada aspek pembelajaran dan materi dapat dilihat pada Tabel 2.

Tabel 2. Nilai Rerata Penilaian Ahli Materi

\begin{tabular}{clcc}
\hline No & \multicolumn{1}{c}{ Aspek } & $\begin{array}{c}\text { Skor } \\
\text { Rerata }\end{array}$ & Kategori \\
\hline 1 & Pembelajaran & 4.64 & Sangat Layak \\
2 & Materi & 4.83 & Sangat Layak \\
3 & Jumlah & & 9,47 \\
4 & Rerata & & 4,73 \\
5 & Kriteria & & Sangat Layak \\
\hline
\end{tabular}

Hasil penilaian ahli media terhadap kelayakan produk ditinjau dari aspek media diketahui bahwa rerata skor sebesar 3, 92 dengan kategori "layak". Penilian ahli media pada media dapat dilihat pada Tabel 3.

Tabel 3. Nilai Rerata Penilaian Ahli Media

\begin{tabular}{clcl}
\hline No & Aspek & $\begin{array}{c}\text { Skor } \\
\text { Rerata }\end{array}$ & Kategori \\
\hline 1 & Media & 3.92 & Layak \\
2 & Rerata & 3.92 & Layak \\
3 & Kriteria & & Layak \\
\hline
\end{tabular}

Pada uji coba lapangan tahap awal terhadap kelayakan produk dengan rerata skor secara keseluruhan sebesar 4,04 dengan kategori "layak". Penilian pada uji coba lapangan tahap awal disajikan pada Tabel 4.

Tabel 4. Nilai Rerata Penilaian Uji Coba Lapangan Tahap Awal

\begin{tabular}{cccc}
\hline No & Aspek & $\begin{array}{c}\text { Skor } \\
\text { Rerata }\end{array}$ & Kategori \\
\hline 1 & Pembelajaran & 4,03 & Layak \\
2 & Materi & 4,07 & Layak \\
3 & Media & 4,04 & Layak \\
4 & Jumlah & 12,14 & \\
5 & Rerata & 4.04 & Layak \\
\hline
\end{tabular}


Pada uji coba lapangan utama rerata skor secara keseluruhan sebesar 4,14 dengan kategori "sangat layak". Penilian pada uji coba lapangan utama disajikan pada Tabel 5.

Tabel 5. Nilai Rerata Penilaian Uji Coba Lapangan Utama

\begin{tabular}{clcc}
\hline No & Aspek & $\begin{array}{c}\text { Skor } \\
\text { Rerata }\end{array}$ & Kategori \\
\hline 1 & Pembelajaran & 4,11 & Sangat Layak \\
2 & Materi & 4,10 & Sangat Layak \\
3 & Media & 4,20 & Sangat Layak \\
4 & Jumlah & 12,41 & \\
5 & Rerata & 4.14 & Sangat Layak \\
\hline
\end{tabular}

Pada uji coba operasional rerata skor secara keseluruhan sebesar 4,19 dengan kategori "sangat layak". Penilian pada uji coba lapangan tahap awal dapat dilihat pada Tabel 5.

Tabel 6. Nilai rerata penilaian uji coba lapangan operasional

\begin{tabular}{cccc}
\hline No & Aspek & $\begin{array}{c}\text { Skor } \\
\text { Rerata }\end{array}$ & Kategori \\
\hline 1 & Pembelajaran & 4,16 & Sangat Layak \\
2 & Materi & 4,17 & Sangat Layak \\
3 & Media & 4,22 & Sangat Layak \\
4 & Jumlah & 12,55 & \\
5 & Rerata & 4,19 & Sangat Layak \\
\hline
\end{tabular}

Berdasarkan data tabel maka diagram keseluruhan hasil penilian terhadap media berdasarkan validator yang terdiri ahli materi dan ahli media, penilaian siswa dan guru pada uji coba lapangan tahap awal, uji coba lapangan utama dan uji coba lapangan operasional yang dikembangakan dapat visualkan dalam diagram pada Gambar 2.

Produk multimedia pembelajaran hasil pengembangan ini juga terbukti efektif meningkatkan hasilbelajar baik dalam aspek pengetahuan dilihat dari rerata skor pre-test dan post-test, aspek sikap, dan aspek keterampilan. Berdasarkan uji efektivitas media yang dikembangkan terbukti dapat meingkatkan hasil belajar siswa hal tersebut tampak pada ketuntasan belajar siswa dengan nilai rata-rata pada post tes mampu melebihi KKM yang ditetapkan dengan skor rata-rata 76,4 dengan kategori “ efektif”. Pada aspek sikap yang meliputi sikap religius, santun, peduli dan meng- hargai sebesar 16.87 atau 84,36\% dengan kategori "sangat baik". Pada aspek keterampilan yang meliputi keterampilan diskusi dan laporan hasil pengamatan video pencemaran sungai citarum sebesar 71.88 dengan kategori "baik".

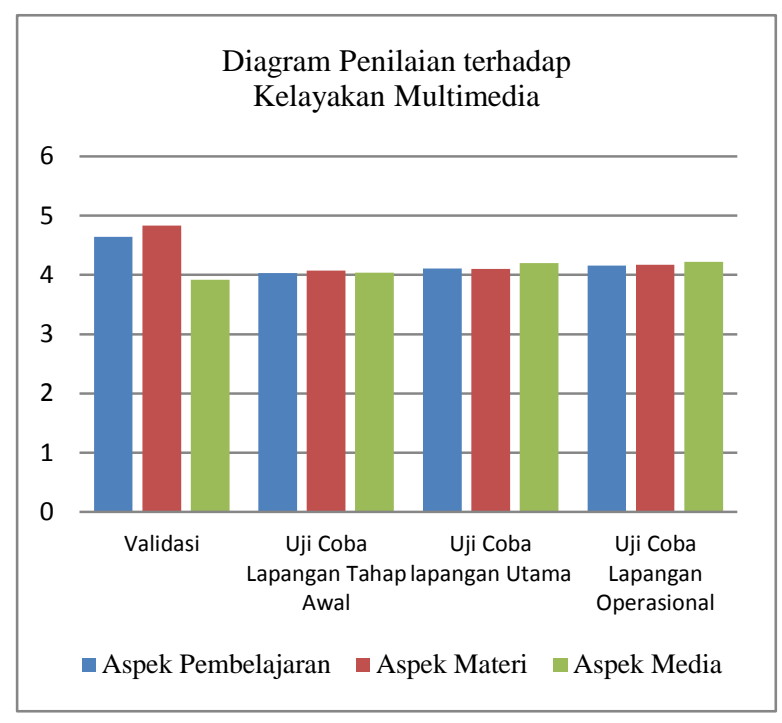

Gambar 2. Diagram Penilaian terhadap
Kelayakan Media

Multimedia ini dikembangakan dengan sistem pengoperasian yang sangat mudah digunakan sehingga tidak megalami kesulitan dalam mengoperasiakannya. Dalam media terdapat berbagai tombol yang menyediakan pilihan yang diinginkan oleh siswa. Selama menggunakan multimedia, terjadi interaksi antara pengguna dalam hal ini adalah siswa dengan media. Siswa dapat bernavigasi sendiri tanpa melihat petunjuk penggunaan media. Kejelasan simbol tombol pada multimedia mempermudah siswa dengan cepat dapat memahami alur dari isi multimedia.

Multimedia ini sangat mendukung pembelajaran mandiri siswa tanpa kehadiran guru, siswa dapat belajar sendiri menggunakan multimedia karena pada multimedia siswa dapat memilih sendiri menu yang menjadi kebutuhan belajarnya. Penjelasan materi yang diperjelas dengan gambar dan animasi, video, akan membuat pemahaman terhadap materi akan lebih mudah. Pada multimedia juga menyediakan menu latihan yang memberikan latihan soal pilihan ganda, essai, dan kegiatan diskusi. Latihan pilihan ganda dapat memberikan penilain dan umpan balik secara langsung kepada siswa, jadi siswa dapat mengetahui kemampuan dalam menguasai materi. Skor 
yang di dapat akan di tampilkan secara langsung, baik itu lulus atau gagal.

Multimedia yang dikembangkan secara sangat menarik, dan materi lebih mudah dipahami karena visualisasi materi berupa gambar dan animasi. Dengan demikian, multimedia dapat membantu siswa belajar secara mandiri bagi sekolah dapat menjadi acuan dalam pembelajaran berbasis teknologi, karena selama ini hanya berpatokan pada buku paket.

Menurut Stemler pada jurnal penelitiannya (1997, p.11), pembelajaran mengunakan multimedia adalah sebuah proses, bukan teknologi yang berperan akan tetapi siswa sebagai pengguna, multimedia sebagai proses pembelajaran yang baru bagi siswa sebagai pengguna dalam hal ini siswa yang mengendalikan proses pembelajaran. Gulbahar \& Guven (2008, p.37), meskipun guru bersedia untuk menggunakan TIK sebagai sumber belajar akan tetapi guru menghadapi masalah dalam kaitannya dengan aksesibilitas ke sumber daya TIK dan kurangnya kesempatan pelatihan bagi guru sehingga memjadi kendala dalam pengembangan pembelajaran menggunakan teknologi seperti multimedia.

Russel \& Water dalam jurnal penelitiannya (2010, p.10) mengenai sebuah survei terhadap pendapat siswa mengenai metode yang yang digunakan dalam pembelajaran IPS bahwa siswa $72 \%$ lebih menyukai pembelajaran IPS menggunakan teknologi seperti internet, fim, video, multimedia dan lain-lain. Hal itu juga dikuatkan oleh Dikshit \& Garg ( 2013, p.194), bahwa multimedia lebih efektif meningkatkan pedagogi siswa dalam berbagai variasi pembelajaran dari pada pembelajaran dengan tatap muka dan ceramah di depan kelas.

Penelitian lain yang dilakukan oleh Berk dalam jurnal (2009, p.20) menunjukkan bahwa pembelajaran secara umum menggunakan verbal dan visual berupa video yang memiliki komponen terbaik dalam proses pembelajaran sehingga pendekatan belajar akan mengaktifkan berbagai indera yang dimiliki oleh siswa sehingga pembelajaran lebih menarik dan tercipta generasi yang tidak buta teknologi. Perbedaan penelitian pada jenis penelitian yakni penelitian pengembangan dan media yang digunakan berupa multimedia sedangkan peneliti merupakan multimedia.
Multimedia merupakan salah satu hasil implementasi dari multimedia dimana terdapat hampir semua konten multimedia yaitu, gambar, video, animasi, text, pengolahan/editing, serta pemberian navigasi untuk menjalankan program tersebut. Dengan adanya navigasi, maka orang yang menjalankan media tersebut dapat menelusuri ke bagianbagian yang diinginkan, sehingga materi lebih jelas dan mendalam. Sehingga terjadi interaksi antara orang yang menjalankan media dengan program dan materi yang ada pada media tersebut.

Pembelajaran IPS yang mempelajari berbagai fenomena sosial di masyarakat sangat tepat jika di jelaskan dengan penggunaan media. Fenomena atau kejadian dapat dihadirkan langsung dalam pembelajaran melalui sebuah media terutama multimedia yang meliputi gambar, suara, dan video. Siswa akan merasakan pengalaman langsung dalam proses pembelajaran. Seiring dengan perkembangan teknonologi media dapat mewakili guru dalam mengajar yang di implementasikan dalam multimedia, siswa dapat belajar secara mandiri tanpa kehadiran guru di kelas. Tentu saja ini akan menjadi sebuah solusi dalam permasalahan pendidikan IPS di kelas yang terjadi selama ini.

Guru dapat memanfaatkan multimedia yang dikembangkan secara praktis dan mudah digunakan karena berupa exe dalam bentuk CD pembelajaran. Media ini sangat tidak asing karena pengoreasiannya sama dengan media powerpoint yang lazim digunakan. Akan tetapi perbedaannya, file berbentuk exe sehingga tidak perlu menginstall sofware lectora.

Media ini sangat baik digunakan sebagai variasi dalam kegiatan pembelajaran karena selama ini dalam proses pembelajaran hanya menggunakan media konvensional, penjelasan proses seperti siklus hidrologi hanya menggunakan gambar sketsa, akan lebih baik ditampilkan seperti animasi yang dikembangkan pada multimedia agar pemahaman siswa lebih jelas dengan adanya gerakan yang menunjukkan siklus tersebut. Selain itu, multimedia ini juga dapat menjadi acuan dalam pengembangan media pembelajaran yang lebih bervariasi dengan memanfaatkan teknologi yang ada sehingga fasilitas yang disediakan di sekolah seperti lab atau proyektor dapat 
di manfaatkan secara optimal dalam proses pembelajaran.

Bagi pihak sekolah, multimedia dapat digunakan sebagai referensi dalam pengembangan media oleh guru di sekolah agar menciptakan pembelajaran yang memanfaatkan teknologi sesuai perkembangan zaman yang membuat pembelajaran di sekolah lebih menarik.

Dengan demikian, dapat disimpulkan bahwa multimedia sangat layak digunakan sebagai media pembelajaran, efektif untuk meningkatkan hasil belajar siswa, sebagai media pembelajarn mandiri bagi siswa, guru dapat memanfaatkan sebagai variasi dalam pembelajaran di kelas dan dapat menjadi acuan dalam pengembangan media pembelajaran berbasis teknologi di sekolah.

\section{Simpulan dan Saran}

Simpulan

Media yang dikembangkan sangat layak digunakan sebagai media pembelajaran yang ditinjau dari aspek pembelajaran, materi dan media, baik menurut ahli meteri dan ahli media. Produk media pembelajaran hasil pengembangan ini terbukti efektif meningkatkan hasil belajar baik dalam aspek pengetahuan dilihat dari rerata skor pre-test dan post-test, aspek sikap, dan aspek keterampilan.

Saran

Berdasarkan kesimpulan, implikasi dan keterbatasan di atas, dapat disarankan sebagai berikut :(1) apabila guru ingin meningkatkan hasil belajar guru sebaiknya menggunakan media pembelajaran berbentuk multimedia berupa CD yang telah dikemas secara menarik (2) Jumlah ahli dalam validator perlu ditambah agar kevalidan materi lebih lebih lengkap, misalnya penambahan ahli materi dan ahli media di tambah sesuai bidang yang ingin dikembangkan. Selain itu, ahli seperti bahasa, ahli desain produk media yang meliputi warna, suara, animasi dan pemilihan gambar (3) Peneliti menyarankan pada pihak pengembang sofware lectora agar perlunya penyempurnaan pada pemutar animasi tanpa flash player karena jika flash player tidak terinstall animasi tidak dapat ditampilkan. Selain itu, perlunya penyempurnaan pada resolusi yang agar compatible atau cocok pada komputer, laptop, dan proyektor. (4) Berda- sarkan penilaian ahli materi, media, guru dan siswa media ini masih memiliki kekurangan pada kedalaman materi yang dikemas dalam media masih belum kompleks cakupannya dalam pembelajaran IPS yang tematik, selain itu penggunaan bahasa masih memiliki skor yang rendah hal itu disebabkan media ini tidak di validasi oleh ahli bahasa. (5) Berdasarkan penilaian ahli materi, media, guru dan siswa media ini masih memiliki keunggulan pada kemenarikan animasi pada penjelasan materi karena proses hidrologi itu sangat menarik disajikan dalam bentuk media yang menggambarkan alur siklus hidrologi. Selain itu, dalam penjelasan dengan adanya gambar yang menjelaskan akan lebih menarik dan menjadi ilustrasi terhadap materi yang di jelaskan secara lisan dalam bentuk visual. Adanya video menjadi suatu kemenarikan dalam sebuah media, oleh sebab itu peneliti mengharapkan agar dalam pengembangan sebuah media, video sangat menarik sebagai pelengkap penjelasan materi secara nyata dalam bentuk audiovisual.

\section{Daftar Pustaka}

Arsyad, A. (2011). Media pembelajaran. Jakarta: PT. Rajawali Press.

Berk, R. A. (2009). Multimedia teaching with video clips: TV, movies, YouTube, and MTVU in the college classroom. International Journal of Technology in Teaching and Learning, Vol 5, 121.

Borg, W. R. \& Gall, M. D. (2003). Educational research: an introduction $\left(7^{\text {th }}\right.$ ed.).New York: Longman, Inc.

Dick, Walter \& Carey, O James .(2009). The systematic design of instruction. New Jersey : Pearson Education Inc.

Dikshit, J \& Garg. (2013). Pedagogic effectiveness of print, interactive multimedia, and online resources: A case study of IGNOU. International Journal of Instruction Vol.6, No.2, 194210.

Djamarah, B,S \& Zain, A. (2006). Strategi belajar mengajar. Jakarta: Rineka Cipta. 
Gulbahar, Y \& Guven, I. (2008). A survey on ICT usage and the perceptions of Social Studies teachers in Turkey. Journal Educational Technology \& Society Vol 3, 37-51.

Januszewski \& Molenda, M. (2008). Educational technology: a definition with commentary. New York: Lawrence Erlbaum Associates.

Kustandi, C \& Sutjipto, B. (2013). Media pembelajaran manual dan digital. Bogor: Ghalia Indonesia.

Mayer, E, R. (2009). Multimedia learning prinsip-prinsip dan aplikasi. (Terjemahan Teguh Wahyu Utomo). Yogyakarta : Pustaka Pelajar.

Munir. (2012). Multimedia konsep dan aplikasi dalam pendidikan. Bandung Alfabeta.

Napitupulu, E. (2013). Pemanfaatan TIK di sekolah minim. Diakses pada tanggal 12 Juli 2014 dari http://edukasi. kompas.com/read/2013/02/15/204028 82/Pemanfaatan.TIK.di.Sekolah.Mini m.)

Reigeluth, C.M \& Chellman. (2009). Instructional-design theories and models volume iii, building a common knowledge base. New York: Taylor \& Francis.

Sadiman, A.S. (2005). Media pendidikan pengertian, pengembangan, dan peman- faatannya. Jakarta: Raja Grafindo Persada.

Sharon, E. (2011). Istructional media and tehnologies for learning. (Terjemahan Arif Rahman). Jakarta: Kencana.

Stemler. K,S. (1997). Educational characteristics of multimedia: a literature review. Journal of Educational Multimedia and Hypermedia Vol 6, 1-16.

Sukarjo. (2005). Evaluasi pembelajaran. Yogyakarta :PPs UNY.

Supardi. (2011). Dasar-dasar ilmu sosial. Yogyakarta : Ombak.

Susilana, R \& Riyana, C. (2008). Media pembelajaran. Bandung: Universitas Pendidikan Indonesia.

William B, Russell III \& Stewart, Waters. (2010) Instructional methods for teaching social studies: a survey of what middle school students like and dislike about Social Studies instruction. Journal for the Liberal Arts and Sciences Vol 2, 7-14.

Yamin, M. (2007). Kiat membelajarkan siswa. Jakarta: Gaung Persada Press Jakarta.

Yudhi, M. (2013). Media pembelajaran: sebuah pendekatan baru. Jakarta: GP Press Group. 